\title{
The science of safety: complications associated with the use of mechanical circulatory support in cardiogenic shock and best practices to maximize safety [version 1; peer review: 2
}

\section{approved]}

\author{
Navin K. Kapur(D1, Evan H. Whitehead ${ }^{1}$, Katherine L. Thayer ${ }^{1}$, Mohit Pahuja (D2 \\ ${ }^{1}$ The Cardiovascular Center for Research and Innovation, Tufts Medical Center, Boston, MA, USA \\ ${ }^{2}$ Division of Cardiology, Detroit Medical Center/Wayne State University School of Medicine, Detroit, MI, USA
}

\author{
V1 First published: 29 Jul 2020, 9(Faculty Rev):794 \\ https://doi.org/10.12688/f1000research.25518.1 \\ Latest published: 29 Jul 2020, 9(Faculty Rev):794 \\ https://doi.org/10.12688/f1000research.25518.1
}

\section{Abstract}

Acute mechanical circulatory support (MCS) devices are widely used in cardiogenic shock (CS) despite a lack of high-quality clinical evidence to guide their use. Multiple devices exist across a spectrum from modest to complete support, and each is associated with unique risks. In this review, we summarize existing data on complications associated with the three most widely used acute MCS platforms: the intra-aortic balloon pump (IABP), Impella systems, and veno-arterial extracorporeal membrane oxygenation (VA-ECMO). We review evidence from available randomized trials and highlight challenges comparing complication rates from case series and comparative observational studies where a lack of granular data precludes appropriate matching of patients by CS severity. We further offer a series of best practices to help shock practitioners minimize the risk of MCS-associated complications and ensure the best possible outcomes for patients.

\section{Keywords}

Safety review, cardiogenic shock, acute mechanical circulatory support, impella, ecmo, intraaortic balloon pump

\section{Open Peer Review \\ Approval Status \\ 1 2 \\ version 1 \\ 29 Jul 2020 \\ Faculty Reviews are review articles written by the prestigious Members of Faculty Opinions. The articles are commissioned and peer reviewed before publication to ensure that the final, published version is comprehensive and accessible. The reviewers who approved the final version are listed with their names and affiliations.}

1. Daniel A. Jones, Barts Heart Centre, London, UK

2. Saraschandra Vallabhajosyula, Mayo Clinic, Rochester, USA

Any comments on the article can be found at the end of the article. 
Corresponding author: Navin K. Kapur (nkapur@tuftsmedicalcenter.org)

Author roles: Kapur NK: Conceptualization, Funding Acquisition, Project Administration, Supervision, Writing - Review \& Editing; Whitehead EH: Conceptualization, Data Curation, Formal Analysis, Investigation, Methodology, Resources, Writing - Original Draft Preparation; Thayer KL: Conceptualization, Data Curation, Formal Analysis, Methodology, Writing - Review \& Editing; Pahuja M: Writing - Review \& Editing

Competing interests: NKK receives consulting/speaker honoraria and institutional grant support from Abbott Laboratories, Abiomed Inc., Boston Scientific, Medtronic, LivaNova, MDStart, and Precardia. EHW, KLT and MP have no competing interests to report.

Grant information: The author(s) declared that no grants were involved in supporting this work.

Copyright: @ 2020 Kapur NK et al. This is an open access article distributed under the terms of the Creative Commons Attribution License, which permits unrestricted use, distribution, and reproduction in any medium, provided the original work is properly cited.

How to cite this article: Kapur NK, Whitehead EH, Thayer KL and Pahuja M. The science of safety: complications associated with the use of mechanical circulatory support in cardiogenic shock and best practices to maximize safety [version 1; peer review: 2 approved] F1000Research 2020, 9(Faculty Rev):794 https://doi.org/10.12688/f1000research.25518.1

First published: 29 Jul 2020, 9(Faculty Rev):794 https://doi.org/10.12688/f1000research.25518.1 


\section{Acute mechanical circulatory support in cardiogenic shock}

Cardiogenic shock (CS) is an advanced state of hemodynamic compromise representing a convergent endpoint of cardiac decompensation resulting from acute myocardial infarction, end-stage heart failure, myocarditis, and various other conditions. In-hospital mortality in CS remains unacceptably high, with recent estimates ranging from $27-51 \%$. Historically, CS has been managed largely with intravenous inotropes and vasopressors, medications which improve systemic perfusion at the cost of worsening myocardial supply/demand imbalance. Despite seeming to temporarily improve hemodynamic indices and traditional markers of tissue perfusion, empiric studies have shown that escalating inotropes and vasopressors fail to meaningfully reverse the downward hemodynamic spiral that occurs in CS, with very poor survival observed in patients requiring multiple agents ${ }^{2}$.

Mechanical circulatory support (MCS) devices are commonly used to augment cardiac output and decouple systemic perfusion from native myocardial energy expenditure in CS. The intraaortic balloon pump (IABP) was first applied in CS in the late 1960s, promising to improve hemodynamics through balloon counterpulsation synchronized with the cardiac cycle ${ }^{3}$. The IABP became widely used and gained a class I indication for CS until the landmark IABP-SHOCK II trial showed that it failed to improve short- or long-term mortality in acute myocardial infarction complicated by CS (AMICS) ${ }^{4-6}$. Over the past decade, several other acute MCS platforms capable of providing much greater support have been developed and adopted to varying degrees in clinical practice. The trans-valvular axial flow pumps such as the Impella device (Abiomed, Danvers, MA) directly unload the left ventricle, capable of providing between 3 and $5.5 \mathrm{~L} /$ minute of flow while reducing native myocardial oxygen demand ${ }^{7}$. A percutaneous right ventricular Impella device (Impella RP) is also available, which bypasses the right ventricle by displacing blood from the right atrium to pulmonary artery ${ }^{8}$.

The TandemHeart device (CardiacAssist, Pittsburgh, PA) consists of a left atrial drainage cannula connected to an extracorporeal centrifugal flow pump, which returns blood to the descending aorta at flow rates of up to $5 \mathrm{~L} /$ minute $^{7}$. Because of the technical complexity and complications associated with the need for trans-septal puncture for delivery of the left atrial drainage cannula, the TandemHeart device is less commonly used in contemporary practice and thus will be only briefly discussed here. Finally, veno-arterial extracorporeal membrane oxygenation (VA-ECMO), a peripheral modification of cardiopulmonary bypass, is the only device which provides full systemic circulatory and respiratory support, though at the cost of increased left ventricular afterload ${ }^{9}$. Recognizing the futility of escalating inotropes as well as the imperative to effectively intervene before impaired systemic perfusion progresses to an irreversible state of widespread metabolic failure, we and others have proposed CS management algorithms which incorporate early application of these advanced MCS platforms, with device selection tailored to the individual patient's hemodynamic profile ${ }^{10-13}$.

\section{Putting recent safety signals into context}

All MCS devices are associated with risk. This risk is increased among patients in CS who are commonly treated with vasoconstrictive agents, anticoagulants, and anti-platelet drugs, and may be exposed to other devices requiring large bore access such as hemodialysis catheters, pulmonary artery catheters, and other venous or arterial sheaths for monitoring and drug delivery. Use of large-bore MCS access along with a requirement for systemic anticoagulation increases the risk for bleeding, limb ischemia, and stroke ${ }^{14}$. Intravascular shear and varying degrees of hemocompatibility with non-biologic surfaces can induce hemolysis, which in combination with systemic inflammation and thromboembolism can predispose to renal failure, with significant prognostic implications ${ }^{15}$. Understanding the relative risks of these various complications with different MCS devices and their implications for device selection in patients has been extremely challenging.

Straightforward comparison of complication rates across devices is possible only by using data from randomized trials in which equivalent patients are randomized to different device strategies. Complication rates observed in randomized trials performed to date are summarized in Table 1. The IABP-SHOCK II trial was the largest randomized trial of an MCS device performed in CS to date and reported low rates of bleeding, limb ischemia, and stroke in both the IABP and medical therapy arms $^{4}$. Two small randomized trials comparing the TandemHeart device to IABP showed a clear signal toward higher rates of bleeding and limb ischemia with TandemHeart, though these trends were significant in only one of the two studies ${ }^{16,17}$. Three small, underpowered randomized trials have been conducted evaluating the use of Impella in CS. The ISAR-SHOCK (Efficacy Study of LV Assist Device to Treat Patients with Cardiogenic Shock) trial was a small study $(n=25)$ comparing the early generation Impella 2.5 to IABP, powered for a surrogate endpoint of hemodynamic improvement 30 minutes after device insertion ${ }^{18}$. A numerically higher incidence of bleeding, hemolysis, and limb ischemia was observed among Impella patients, though the sample was too small to evaluate the significance of these trends. The IMPRESS in Severe Shock (IMPella versus IABP Reduces mortality in STEMI patients treated with primary PCI in Severe cardiogenic SHOCK) trial was designed to compare all-cause mortality between IABP and the Impella $\mathrm{CP}$ in AMICS but ended up being completed as an exploratory safety trial because of miscalculation of expected event rates ${ }^{19}$. A trend toward higher rates of bleeding and hemolysis was observed with the Impella $\mathrm{CP}$, though the small sample size limited any conclusive findings. Finally, the IMPELLA-STIC trial compared IABP alone to IABP plus Impella 5.0 in 12 patients with AMICS and found a significantly higher rate of major bleeding in the combined device group, though the study was too small to evaluate the significance of other complication trends ${ }^{20}$. To date, only one randomized trial has evaluated the use of VA-ECMO in CS: the Extracorporeal Life Support in cardiogenic Shock complicating acute myocardial infarction (ECLS-SHOCK) trial randomized 42 post-arrest AMICS patients to VA-ECMO or no MCS and found similar rates of complications between groups, though again the study 


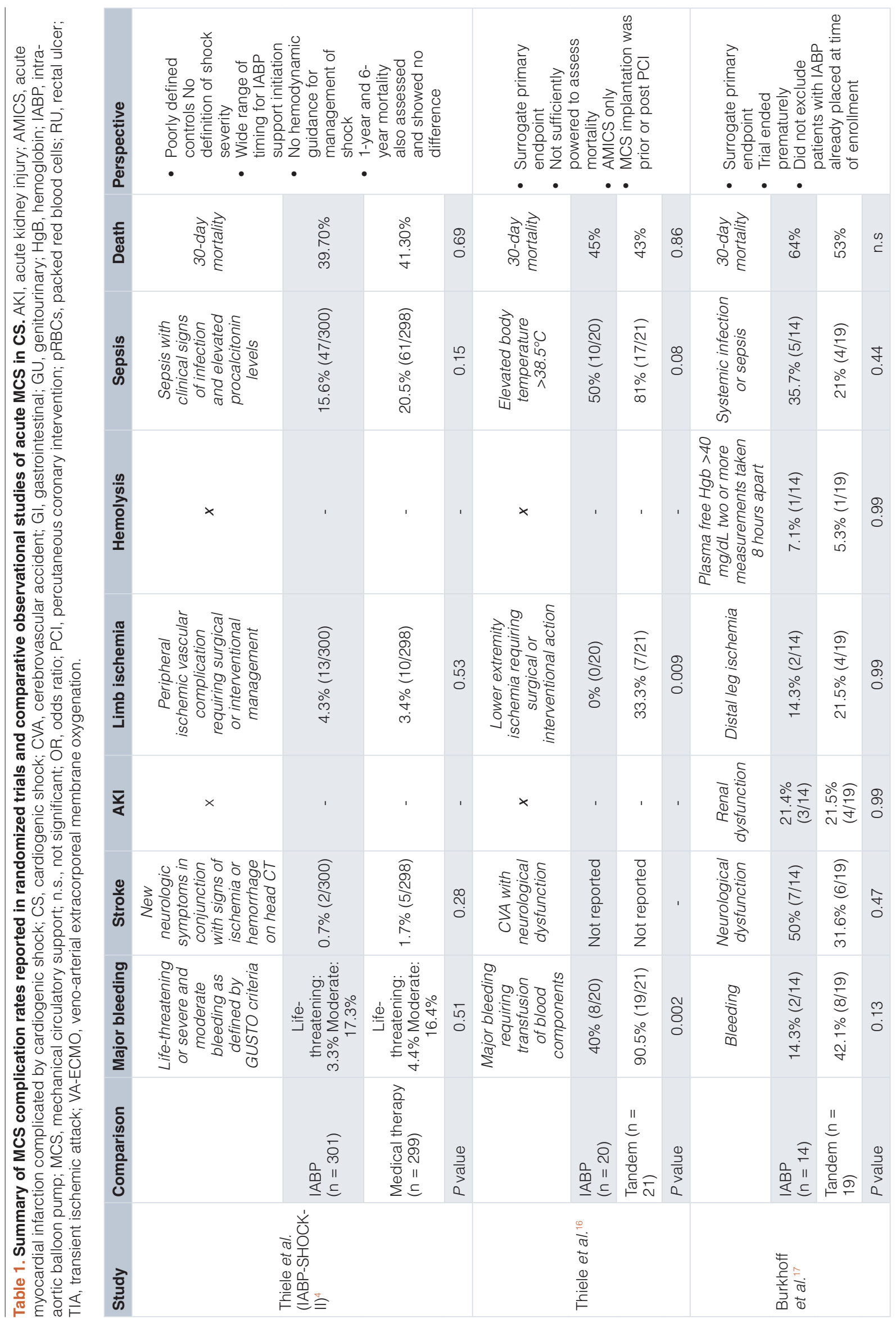




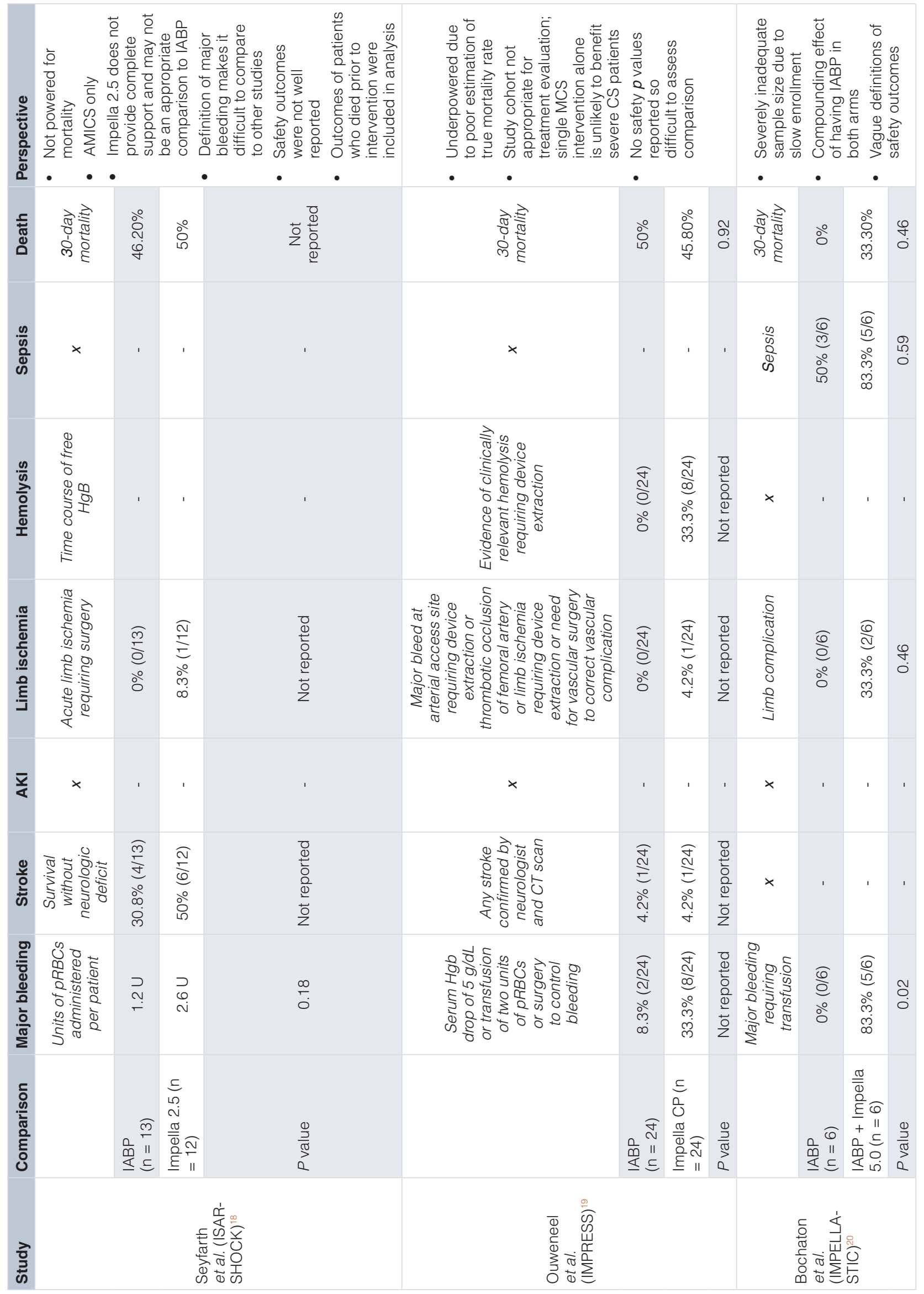




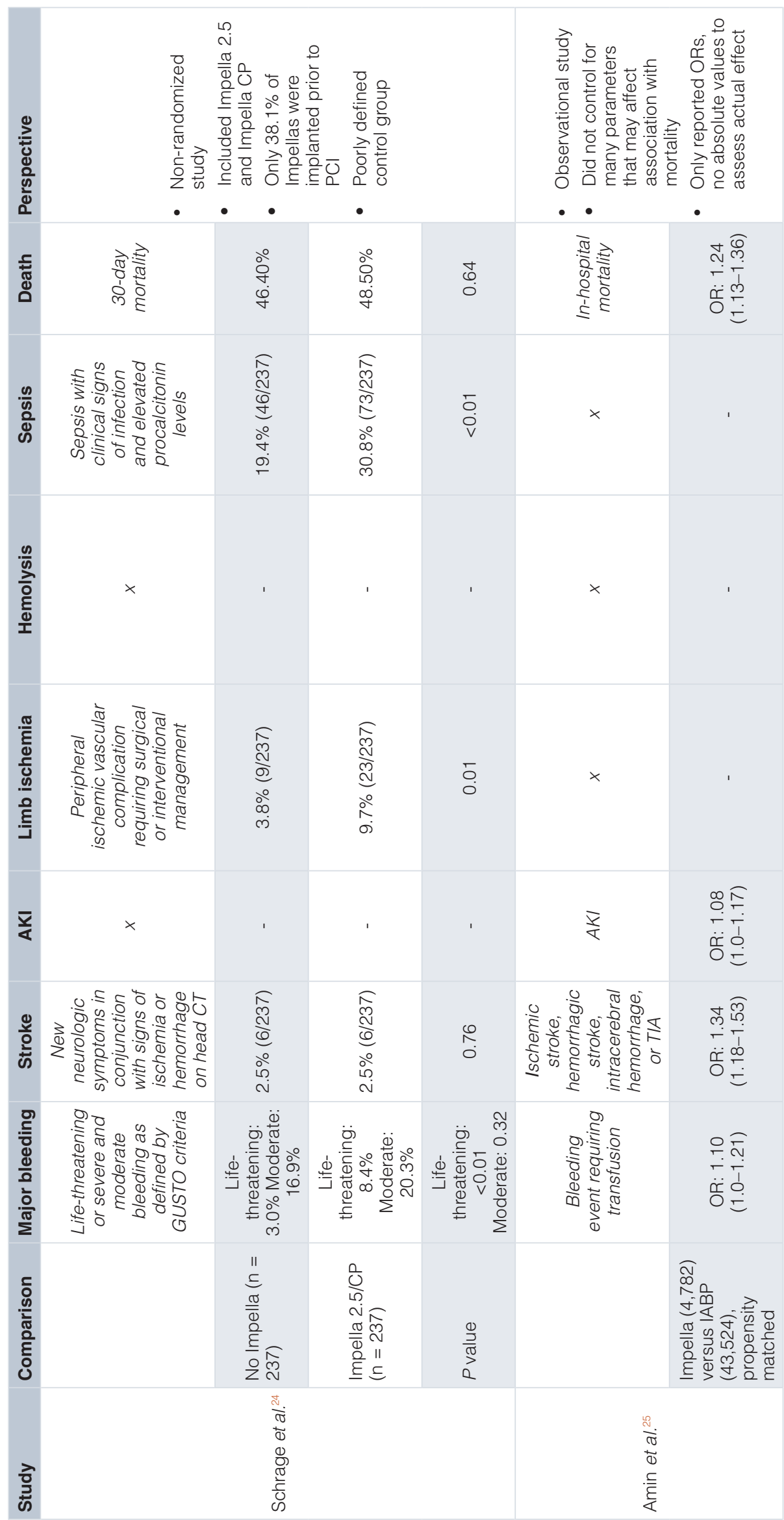




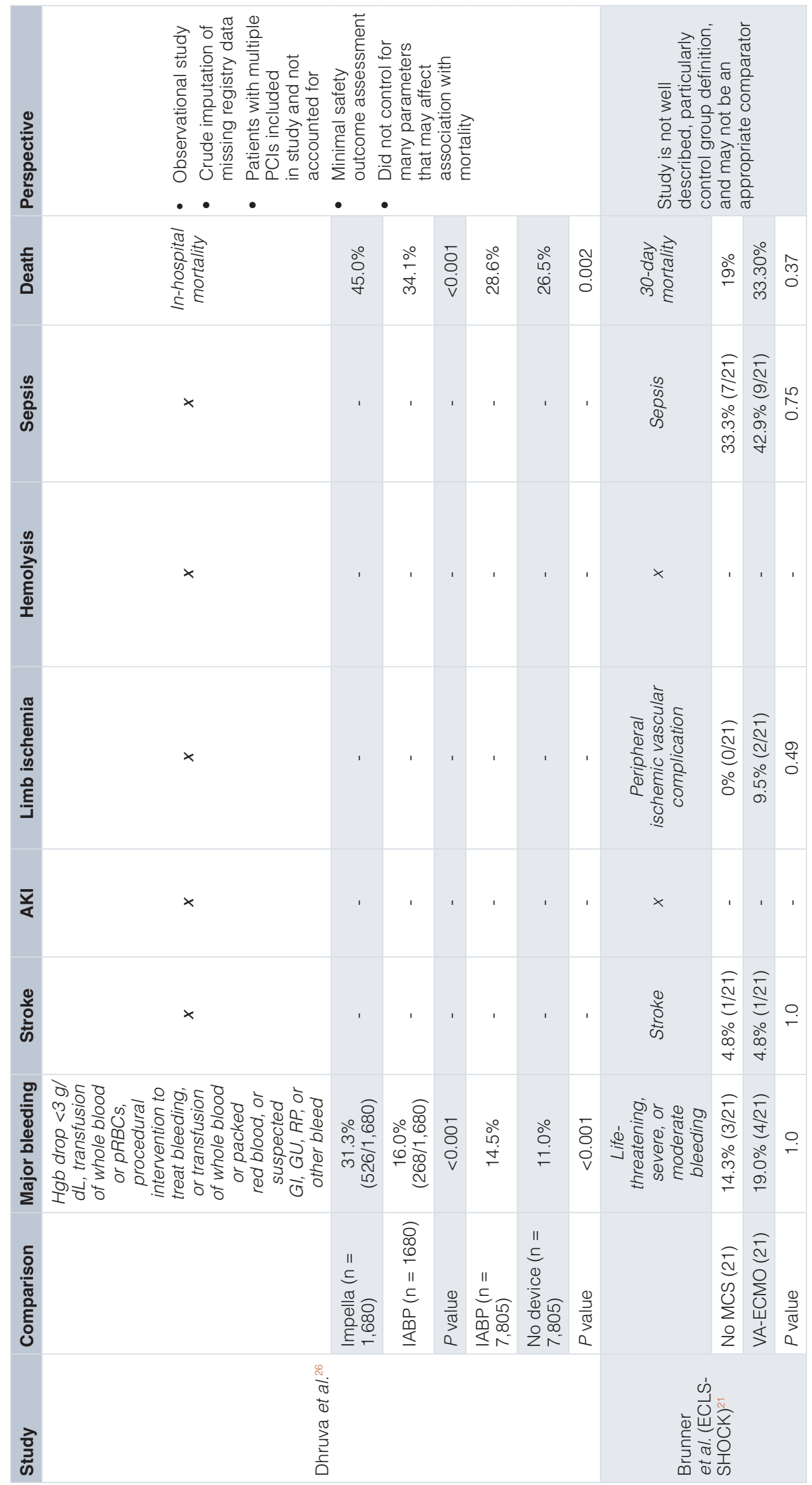


was underpowered for clinical outcomes including safety conclusions $^{21}$.

Given the paucity of sufficiently powered randomized trials, most data on complication rates come from observational case series and registries, which are summarized in Table 2. Despite inconsistent reporting and variability in outcome definitions, several trends are apparent from these data. First, higher rates of bleeding and vascular injury are associated with devices requiring larger bore access including Impella (13-14 French access sheaths) and VA-ECMO (21-27 French venous cannulas plus 15-21 French arterial cannulas) compared to IABP (8-9 French access). Similarly, rates of stroke and limb ischemia are increased with Impella compared with IABP, and higher still with VA-ECMO. Two recent analyses by Pahuja et al. comparing rates of stroke, bleeding, and

Table 2. Complication rates associated with IABP, Impella, and VA-ECMO from observational studies in cardiogenic shock. Death represents either 30-day or in-hospital mortality, whichever was reported in the individual study. AKI, acute kidney injury; IABP, intra-aortic balloon pump; VA-ECMO, veno-arterial extracorporeal membrane oxygenation

\begin{tabular}{|c|c|c|c|c|c|c|c|c|c|}
\hline IABP & Study & $\mathrm{n}$ & Bleeding (\%) & Stroke (\%) & AKI (\%) & $\begin{array}{c}\text { Limb } \\
\text { ischemia (\%) }\end{array}$ & Hemolysis (\%) & Sepsis (\%) & Death (\%) \\
\hline & Tehrani et al. ${ }^{10}$ & 55 & 9.1 & - & 23.6 & 7.3 & 0.0 & - & - \\
\hline & Alushi et al. ${ }^{33}$ & 54 & 7.4 & 1.8 & - & 0.0 & - & - & 52.0 \\
\hline & Pieri et al..$^{34}$ & 36 & 36.1 & 8.3 & - & 2.8 & 0.0 & 36.0 & 6.0 \\
\hline & Ferguson et al. ${ }^{35}$ & 16,909 & 2.4 & - & - & 2.9 & - & - & 21.2 \\
\hline & Cohen et al..$^{36}$ & 22,663 & 0.9 & - & - & 0.9 & - & - & 21.3 \\
\hline & Stone et al. ${ }^{37}$ & 5,495 & 4.3 & - & - & 2.3 & - & - & 20.0 \\
\hline & Siriwardena et al. ${ }^{38}$ & 645 & 2.9 & 2.3 & 16.6 & 2.6 & - & - & - \\
\hline & Cohen et al. ${ }^{39}$ & 1,119 & 4.6 & 3.3 & - & - & - & - & - \\
\hline & Valente et al. ${ }^{40}$ & 414 & 7.2 & - & - & 2.4 & - & - & - \\
\hline & Davidicius et al. ${ }^{41}$ & 360 & 19.0 & - & - & 4.0 & - & - & - \\
\hline & Ternus et al. ${ }^{42}$ & 682 & 0.6 & - & - & 1.3 & 0.0 & - & 18.5 \\
\hline & Schwartz et al. ${ }^{43}$ & 50 & 24.0 & 4.0 & - & 6.0 & - & - & 34.0 \\
\hline & Mackenzie et al..$^{44}$ & 100 & 2.0 & - & - & 25.0 & - & - & 40.0 \\
\hline & Ozen et al. ${ }^{45}$ & 3,135 & 1.4 & - & - & 12.3 & 0.7 & - & 25.9 \\
\hline & Arceo et al. ${ }^{46}$ & 212 & 2.4 & - & - & 5.7 & - & - & 45.0 \\
\hline & Dick et al. ${ }^{47}$ & 187 & - & - & - & 2.5 & - & - & 7.2 \\
\hline & Eltchaninoff et al. ${ }^{48}$ & 240 & 3.3 & - & - & 12.9 & - & 0.4 & 24.0 \\
\hline & Meisel et al. ${ }^{49}$ & 161 & 2.5 & - & - & 2.5 & - & - & 7.2 \\
\hline & Pahuja et al..22,23 & 86,796 & 19.4 & 3.1 & - & 0.9 & - & - & 25.8 \\
\hline & Weighted average & & 12.9 & 3.1 & 17.2 & 1.5 & 0.6 & 5.0 & 24.2 \\
\hline \multirow[t]{11}{*}{ Impella } & & $\mathbf{n}$ & Bleeding (\%) & Stroke (\%) & AKI (\%) & $\begin{array}{c}\text { Limb } \\
\text { ischemia (\%) }\end{array}$ & Hemolysis (\%) & Sepsis (\%) & Death (\%) \\
\hline & Tehrani et al. ${ }^{11}$ & 67 & 4.5 & - & 25.4 & 4.5 & 10.5 & - & - \\
\hline & Annamalai et al. ${ }^{50}$ & 34 & 20.6 & 5.9 & 47.1 & 8.8 & 11.8 & - & 38.0 \\
\hline & Alushi et al. ${ }^{33}$ & 62 & 14.5 & 1.6 & - & 8.0 & - & - & 67.0 \\
\hline & O'Neill et al. ${ }^{51}$ & 154 & 20.1 & 1.9 & - & - & - & - & - \\
\hline & Jensen et al. ${ }^{52}$ & 109 & 59.0 & 0.0 & - & 10.1 & 11.9 & - & - \\
\hline & Karatolios et al..$^{53}$ & 27 & 62.9 & - & - & 3.7 & - & - & - \\
\hline & Karami et al. ${ }^{54}$ & 90 & 23.3 & 4.4 & - & 2.2 & 6.7 & - & 52.2 \\
\hline & Pieri et al. ${ }^{34}$ & 28 & 35.7 & 7.1 & - & 18.0 & 32.0 & 29.0 & 21.0 \\
\hline & Basir et al..$^{55}$ & 171 & 7.0 & - & - & 4.1 & - & 28.0 & - \\
\hline & Ternus et al. ${ }^{42}$ & 96 & 5.2 & - & - & 2.1 & 1.0 & - & 30.2 \\
\hline
\end{tabular}




\begin{tabular}{|c|c|c|c|c|c|c|c|c|c|}
\hline Impella & & $\mathrm{n}$ & Bleeding (\%) & Stroke (\%) & AKI (\%) & $\begin{array}{c}\text { Limb } \\
\text { ischemia (\%) }\end{array}$ & Hemolysis (\%) & Sepsis (\%) & Death (\%) \\
\hline & Kaki et al. ${ }^{56}$ & 17 & 5.9 & 5.9 & 41.0 & 5.9 & - & - & 70.6 \\
\hline & Lauten et al. ${ }^{57}$ & 120 & 28.4 & 1.7 & 31.7 & - & 7.5 & - & 64.2 \\
\hline & Ouweneel et al..$^{58}$ & 112 & 25.0 & 3.6 & - & - & 7.1 & - & 65.0 \\
\hline & Badiye et al. ${ }^{59}$ & 40 & - & - & 42.0 & - & 62.5 & - & 32.5 \\
\hline & Esposito et al. ${ }^{60}$ & 23 & - & - & - & - & 30.4 & - & 57.0 \\
\hline & Schwartz et al. ${ }^{43}$ & 7 & 57.0 & 0.0 & - & 0.0 & - & - & 14.0 \\
\hline & Garan et al..$^{12}$ & 31 & - & 12.9 & - & 12.9 & - & - & 45.2 \\
\hline & Lamarche et al. ${ }^{61}$ & 29 & - & - & - & 0.0 & - & - & 38.0 \\
\hline & $\begin{array}{l}\text { Anderson et al. }{ }^{62} \\
\text { (RP) }\end{array}$ & 60 & 48.3 & - & - & - & 21.7 & - & 26.7 \\
\hline & Pahuja et al. ${ }^{22,23}$ & 2,079 & 29.9 & 5.6 & - & 3.6 & - & - & 41.0 \\
\hline & Weighted average & & 27.7 & 4.9 & 34.1 & 4.2 & 13.1 & 28.1 & 43.1 \\
\hline \multirow[t]{30}{*}{ ECMO } & & $\mathbf{n}$ & Bleeding (\%) & Stroke (\%) & AKI (\%) & $\begin{array}{c}\text { Limb } \\
\text { ischemia (\%) }\end{array}$ & Hemolysis (\%) & Sepsis (\%) & Death (\%) \\
\hline & Tehrani et al. ${ }^{11}$ & 31 & 16.1 & - & 51.6 & 19.4 & 38.7 & - & - \\
\hline & Karami et al. ${ }^{54}$ & 38 & 31.6 & 10.5 & - & 5.3 & 0.0 & - & 47.4 \\
\hline & $\begin{array}{l}\text { Chamogeorgakis } \\
\text { et al. }\end{array}$ & 61 & - & - & - & 13.1 & - & - & 50.8 \\
\hline & Hoefer et al. ${ }^{64}$ & 131 & 11.5 & 2.3 & - & 1.5 & - & - & - \\
\hline & Koerner et al. ${ }^{65}$ & 184 & 22.3 & 4.9 & 16.3 & 4.3 & 9.2 & 18.5 & 61.0 \\
\hline & Lorusso et al. ${ }^{66}$ & 4,522 & - & 5.4 & - & - & - & - & - \\
\hline & Garan et al. ${ }^{12}$ & 20 & - & 25.0 & - & 10.0 & - & - & 45.0 \\
\hline & Kolla et al..$^{67}$ & 27 & 16.0 & 7.4 & 56.0 & - & - & - & 70.0 \\
\hline & Gulkarov et al. ${ }^{68}$ & 71 & 4.1 & 14.1 & 45.1 & 19.7 & - & - & 53.5 \\
\hline & Yau et al. ${ }^{69}$ & 154 & - & - & - & 22.0 & - & - & 59.7 \\
\hline & Avalli et al. ${ }^{70}$ & 100 & - & - & - & 35.0 & - & - & 72.0 \\
\hline & Wong et al. ${ }^{71}$ & 193 & 18 & 9.0 & - & 11.0 & - & - & 61.0 \\
\hline & Ranney et al..$^{72}$ & 80 & - & - & - & 21.3 & - & - & 60.0 \\
\hline & Foley et al. ${ }^{73}$ & 43 & - & - & - & 16.3 & - & - & 79.0 \\
\hline & Lamb et al. ${ }^{74}$ & 91 & - & - & - & 13.2 & - & - & 58.0 \\
\hline & Belle et al. ${ }^{75}$ & 51 & 39.2 & 3.9 & - & 17.6 & 13.7 & 13.7 & 72.5 \\
\hline & Bermudez et al. ${ }^{76}$ & 42 & & 11.9 & 40.5 & 14.3 & - & - & 62.0 \\
\hline & Kim et al. ${ }^{77}$ & 27 & 14.2 & - & 37.0 & - & - & - & 41.7 \\
\hline & Esper et al..$^{78}$ & 18 & 94.4 & 5.6 & - & 22.2 & - & - & 33.0 \\
\hline & Loforte et al. ${ }^{79}$ & 73 & 50.7 & 15.1 & 52.0 & 54.8 & - & 15.1 & 54.8 \\
\hline & Moraca et al..$^{80}$ & 26 & - & 7.7 & 34.6 & 7.7 & - & - & 35.0 \\
\hline & Pagani et al. ${ }^{81}$ & 33 & - & 0.9 & 30.3 & - & - & - & 64.0 \\
\hline & Wu et al..$^{82}$ & 60 & - & - & 31.7 & 10.0 & - & - & 47.0 \\
\hline & Formica et al. ${ }^{83}$ & 42 & 54.8 & 26.2 & 47.6 & 21.4 & - & - & 61.9 \\
\hline & Lamarche et al. ${ }^{61}$ & 32 & - & - & - & 15.6 & - & - & 44.0 \\
\hline & Batra et al..$^{84}$ & 1,286 & 32.3 & - & 21.1 & - & - & - & 54.1 \\
\hline & $\begin{array}{l}\text { Vallabhajosyula } \\
\text { et al. }{ }^{85}\end{array}$ & 4,608 & 25.3 & 10.8 & - & - & - & - & 57.7 \\
\hline & Pahuja et al..22,23 & 444 & 54.2 & 9.7 & - & 7.7 & - & - & 55.9 \\
\hline & Weighted average & & 28.2 & 8.2 & 25.6 & 14.3 & 11.8 & 16.9 & 57.2 \\
\hline
\end{tabular}


limb ischemia among AMICS patients treated with IABP, percutaneous VADs (Impella or TandemHeart), or VA-ECMO are exemplary of these trends. In this large sample, stroke was observed in $3.1 \%$ of patients with IABP, $5.6 \%$ of those with pVADs, and $9.7 \%$ of those treated with VA-ECMO. Similarly, bleeding occurred in $19.4 \%, 29.9 \%$, and $54.2 \%$ of each group, respectively, while limb ischemia occurred in $0.9 \%, 3.6 \%$, and $7.7 \%$, respectively. All of these complications were associated with increased length of stay and hospitalization $\operatorname{costs}^{22,23}$. While it stands to reason that more invasive devices would lead to higher complication rates, it must be noted that these observational studies do not account for significant baseline differences between the real-world patients in whom the devices are deployed. Crude insight about the severity of shock across device cohorts can be gained by comparing the short-term mortality rates in Table 2. The lowest mortality is observed in patients treated with IABP (24\%), which may be related to the selection of patients with "less-severe" CS who do not require high levels of hemodynamic support. In contrast, higher flow devices such as Impella may be chosen for patients with more severe CS, as reflected in a significantly higher mortality rate of $43.1 \%$. Finally, as it is the only device capable of providing both circulatory and respiratory support, VA-ECMO is often applied emergently for patients with cardiac arrest or severe CS, reflected in an extremely high observed mortality rate of $57.2 \%$. Some of the observed disparity in complication rates across device cohorts may therefore be driven by baseline differences in illness severity, in addition to device factors. Accordingly, lower complication rates have been observed when these advanced devices have been applied in less-severely-ill cohorts. The recent STEMI-Door-to-Unload (STEMI-DTU) pilot trial tested the safety and feasibility of Impella CP use in 50 patients with anterior STEMI, without CS. In this cohort with $4 \%$ overall mortality, complication rates were quite low: bleeding occurred in $14 \%$, stroke in $2 \%$, renal dysfunction in $4 \%$, and hemolysis in $2 \%{ }^{89}$. Two patients $(4 \%)$ had major vascular events related to flow-limiting dissections of the femoral artery at device removal, with no device related mortality observed.

A final class of studies which have been used to compare relative complication rates between devices are comparative observational analyses, which attempt to adjust for the significant baseline differences observed in cases series by attempting to match patients across available clinical variables. Three such studies have recently spurred substantial debate about complications related to Impella use. Schrage et al. performed a matched analysis comparing $237 \mathrm{CS}$ patients treated with Impella in 13 European centers to 237 matched patients taken from both arms (IABP and medical therapy) of the IABP-SHOCK II trial ${ }^{24}$. Amin et al. identified patients undergoing PCI with MCS (linked by same-day billing data), some of whom had CS, and performed a propensity matched analysis comparing those managed with Impella with those managed by $\mathrm{IABP}^{25}$. Finally, Dhruva et al. linked two registries to identify AMICS patients managed with Impella or IABP, matched for 75 baseline variables (though, notably, lactate and hemodynamic parameters were not available for matching ${ }^{26}$. Each study reported a higher rate of complications associated with Impella compared to IABP. Even more striking, the Amin and Dhruva studies reported a significantly higher rate of in-hospital mortality in patients treated with Impella, raising the concern that the additional complications associated with Impella may translate to higher mortality. While these analyses corroborate the trends observed in observational case series as summarized in Table 2, their salience ultimately depends on the validity of their respective mortality comparisons. As previously discussed, it is relatively obvious why larger sheath sizes would cause higher rates of bleeding and limb ischemia; whether morbidity from these complications outweighs the benefits afforded by greater hemodynamic support in patients with severe shock for whom an IABP would be inadequate remains unanswered. We argue that this question can be properly answered only through trials comparing CS patients randomized to different devices and powered for hard clinical endpoints. No amount of propensity matching-particularly when the most well-validated prognostic variables in CS such as central venous pressure, lactate, and cardiac power output are missing-can account for the vast baseline differences between real-world patients being managed with these different devices. The ongoing DanGer shock trial and other trials may shed light on these critical questions ${ }^{27}$.

\section{Moving forward without data}

In the absence of high-quality randomized data clarifying the net risks and benefits of MCS platforms in CS, practitioners still need to move forward and manage individual patients with CS. Recognizing that there are likely higher rates of at least some complications (bleeding, limb ischemia, and hemolysis) with Impella and VA-ECMO compared to IABP, shock practitioners should redouble their efforts to adhere to the following best practices.

\section{Rapid, coordinated multi-specialty evaluation of patients} with suspected cardiogenic shock

Institutions should design structured responses (such as the 'Shock Team') to ensure that patients with suspected CS are rapidly identified and evaluated by qualified practitioners so that necessary resources can be urgently made available and evaluations begun regarding the likelihood of recovery or candidacy for durable MCS or transplant. Depending on the suspected inciting insult and local staffing patterns, the shock team might include interventional cardiologists, heart failure specialists, (cardiac) intensivists, and cardiac/vascular surgeons along with perfusionists and critical care nurses. Some have suggested that the cath lab be used as a default staging ground where right heart catheterization, coronary angiography, and fluoroscopic MCS insertion can all be rapidly performed ${ }^{11}$.

\section{Comprehensive invasive hemodynamic assessment to guide device selection and management}

Critical to maximizing the risks and benefits of MCS is the use of objective hemodynamic assessment using pulmonary artery catheters (PACs) to guide device selection. Just as it is important to identify the crashing patient with severe biventricular 
congestion who is unlikely to stabilize with IABP alone, it is equally important to identify the STEMI patient with isolated left ventricular failure well-suited for left-sided Impella, sparing them the additional complications of a more invasive device like VA-ECMO. We and others have proposed algorithms for device selection based on the ventricular congestive profile and validated indices of right ventricular function such as pulmonary artery pulsatility index (PAPi), along with the presence of concurrent respiratory failure ${ }^{10,12}$. Recent data suggest that algorithms incorporating hemodynamically guided decision-making may lead to improved survival in AMICS (Figure 1), though observational studies directly examining associations between PAC use and clinical outcomes in CS have yielded mixed results ${ }^{11,28-31}$.

\section{Fastidious prevention of and monitoring for the development of complications}

Many complications can be avoided or their impact minimized if recognized and managed promptly. For example, a careful vascular assessment should be performed daily to monitor for signs of limb ischemia, which may require intervention such as external bypass or addition of a distal perfusion catheter. Similarly, markers of hemolysis should be continually tracked to assess the need for device repositioning and thorough neurologic exams performed to identify signs of stroke, which can be particularly difficult to recognize in unconscious patients. In ECMO patients, right upper extremity oxygen saturation and pulmonary capillary wedge pressure should be continuously monitored for the development of Harlequin syndrome and left ventricular distension, which may require optimization of ventilator settings, upgrade to a VAV-ECMO configuration, or addition of a left ventricular vent ${ }^{9}$. We would refer readers to a comprehensive review by Subramaniam and colleagues for further discussion of risk factors and strategies to reduce complications from acute MCS devices ${ }^{14}$.

\section{Continuous re-assessment to guide device weaning or escalation}

Aside from complications occurring at the time of device insertion or removal, most occur as a function of time on support. Multimodal data (labs, hemodynamic parameters, echocardiography) should be continuously re-integrated to assess for the possibility of device weaning or the need for escalation. Specific thresholds (cardiac power output <0.6, PAPi $<0.9$ ) have been proposed to guide consideration of escalation or addition of right-sided support, though specific device algorithms will depend on local availability ${ }^{30}$.

\section{Implementation of best practices for device removal}

Large bore access devices above 17Fr are commonly referred to vascular surgery for removal. However, with emerging techniques, devices ranging from $12 \mathrm{Fr}$ to $17 \mathrm{Fr}$ may be removed with percutaneous closure approaches. The Perclose device (Abbott Inc) can be used at the time of device implantation (pre-closure approach) or at the time of device removal (post-closure approach) to rapidly achieve hemostasis. The

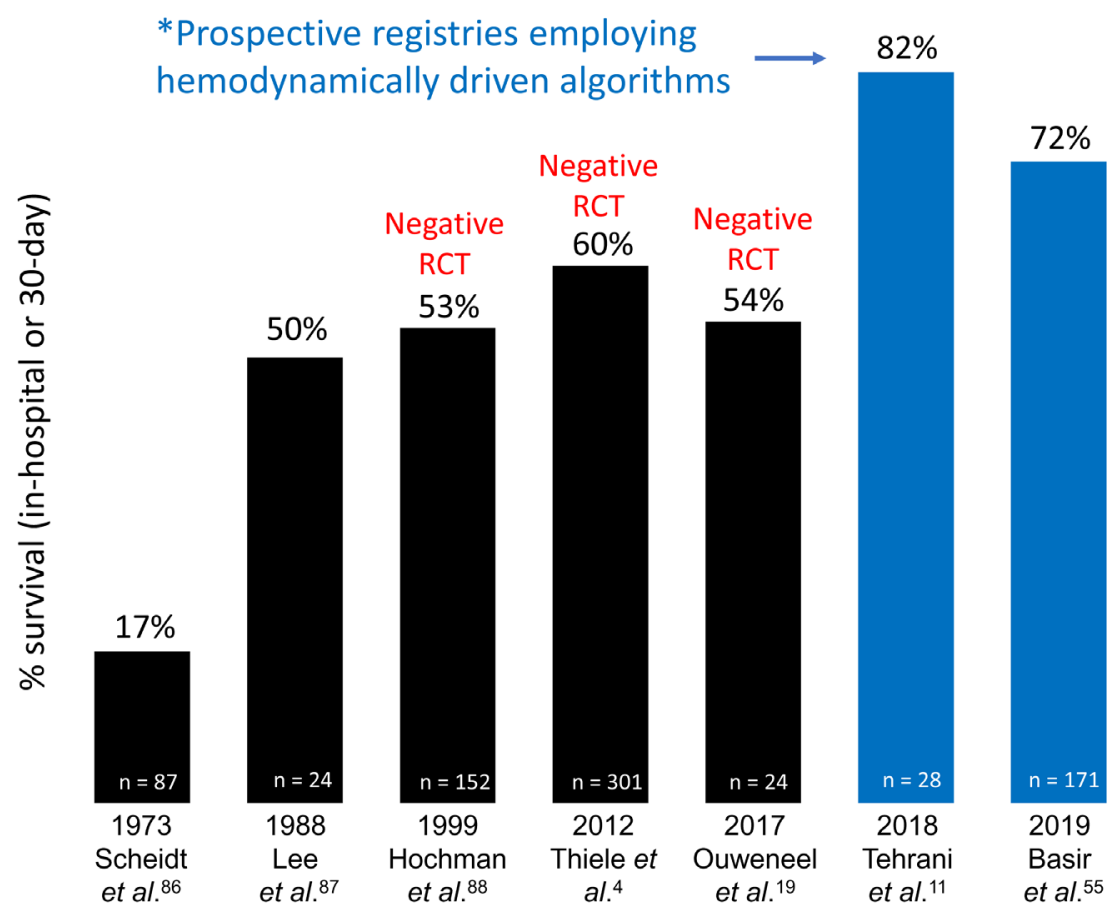

Figure 1. Survival and studies in acute myocardial infarction cardiogenic shock. Two recent prospective registries employing a hemodynamically driven treatment algorithm have reported higher survival rates compared to several recent randomized controlled trials (RCTs) that failed to use hemodynamic data to guide device selection or device management. 
Manta closure device (Teleflex Inc) has recently been introduced and may represent another approach for percutaneous vascular hemostasis. The introduction of the Impella $\mathrm{CP}$ with a sidearm access port allows for device removal and post-closure, thereby mitigating vascular complication risk at the time of device removal ${ }^{32}$. Each operator must develop these technical skills to improve outcomes.

\section{Conclusion}

CS is a complex clinical syndrome that remains a major cause of global mortality and morbidity. MCS device utilization is growing for cardiogenic shock, though each MCS platform is associated with risks. High-quality randomized controlled trials evaluating the use of MCS devices for CS are currently lacking but are in development. Recent reports utilizing administrative datasets and retrospective registries are of limited value other than to raise awareness that randomized controlled trials are needed to improve outcomes for patients. Progress in the field will be made only when high-quality randomized trials are conducted in defined populations, powered for all-cause mortality. The decision to place an advanced device should be made by an experienced shock practitioner or team using the most complete information possible. In the meantime, clinicians should educate themselves about hemodynamically driven decision-making algorithms and best practices to reduce complications associated with each MCS platform.
1. van Diepen S, Katz JN, Albert NM, et al.: Contemporary Management of Cardiogenic Shock: A Scientific Statement From the American Heart Association. Circulation. 2017; 136(6): e232-e268. PubMed Abstract | Publisher Full Text

2. Basir MB, Schreiber TL, Grines CL, et al.: Effect of Early Initiation of Mechanical Circulatory Support on Survival in Cardiogenic Shock. Am J Cardiol. 2017; 119(6): 845-51.

PubMed Abstract | Publisher Full Text | Faculty Opinions Recommendation

3. Parissis H, Graham V, Lampridis S, et al:: IABP: History-evolutionpathophysiology-indications: what we need to know. J Cardiothorac Surg. 2016; 11(1): 122.

PubMed Abstract | Publisher Full Text | Free Full Text

4. Thiele H, Zeymer U, Neumann FJ, et al.: Intraaortic balloon support for myocardial infarction with cardiogenic shock. N Engl J Med. 2012; 367(14): 1287-96.

PubMed Abstract | Publisher Full Text | Faculty Opinions Recommendation

5. Thiele H, Zeymer U, Neumann FJ, et al:: Intra-aortic balloon counterpulsation in acute myocardial infarction complicated by cardiogenic shock (IABP-SHOCK II): Final 12 month results of a randomised, open-label trial. Lancet. 2013; 382(9905): 1638-45.

PubMed Abstract | Publisher Full Text | Faculty Opinions Recommendation

6. Thiele H, Zeymer U, Thelemann N, et al:: Intraaortic Balloon Pump in Cardiogenic Shock Complicating Acute Myocardial Infarction: Long-Term 6-Year Outcome of the Randomized IABP-SHOCK II Trial. Circulation. 2018. PubMed Abstract | Publisher Full Text | Faculty Opinions Recommendation

7. Briceno N, Kapur NK, Perera D: Percutaneous mechanical circulatory support: Current concepts and future directions. Heart. 2016; 102(18): 1494-507. PubMed Abstract | Publisher Full Text

8. Kapur NK, Esposito ML, Bader Y, et al:: Mechanical Circulatory Support Devices for Acute Right Ventricular Failure. Circulation. 2017; 136(3): 314-26. PubMed Abstract | Publisher Full Text

9. C Guglin M, Zucker MJ, Bazan VM, et al: Venoarterial ECMO for Adults: JACC Scientific Expert Panel. J Am Coll Cardiol. 2019; 73(6): 698-716. PubMed Abstract | Publisher Full Text | Faculty Opinions Recommendation

10. Esposito ML, Kapur NK: Acute mechanical circulatory support for cardiogenic shock: The "door to support" time. F1000Res. 2017; 6: 737. PubMed Abstract | Publisher Full Text | Free Full Text

11. C Tehrani BN, Truesdell AG, Sherwood MW, et al.: Standardized Team-Based Care for Cardiogenic Shock. J Am Coll Cardiol. 2019; 73(13): 1659-69. PubMed Abstract | Publisher Full Text | Faculty Opinions Recommendation

12. C Garan AR, Takeda K, Salna M, et al.: Prospective Comparison of a Percutaneous Ventricular Assist Device and Venoarterial Extracorporeal Membrane Oxygenation for Patients With Cardiogenic Shock Following Acute Myocardial Infarction. J Am Heart Assoc. 2019; 8(9): e012171. PubMed Abstract | Publisher Full Text | Free Full Text | Faculty Opinions Recommendation

13. Korabathina R, Heffernan KS, Paruchuri V, et al:: The pulmonary artery pulsatility index identifies severe right ventricular dysfunction in acute inferior myocardial infarction. Catheter Cardiovasc Interv. 2012; 80(4): 593-600. PubMed Abstract | Publisher Full Text
14. Subramaniam AV, Barsness GW, Vallabhajosyula S, et al.: Complications of Temporary Percutaneous Mechanical Circulatory Support for Cardiogenic Shock: An Appraisal of Contemporary Literature. Cardiol Ther. 2019; 8(2): 211-28.

PubMed Abstract | Publisher Full Text | Free Full Text | Faculty Opinions Recommendation

15. Villa G, Katz N, Ronco C, et al.: Extracorporeal Membrane Oxygenation and the Kidney. Cardiorenal Med. 2015; 6(1): 50-60.

PubMed Abstract | Publisher Full Text | Free Full Text

16. Thiele $\mathrm{H}$, Sick $\mathrm{P}$, Boudriot $\mathrm{E}$, et al.: Randomized comparison of intra-aortic balloon support with a percutaneous left ventricular assist device in patients with revascularized acute myocardial infarction complicated by cardiogenic shock. Eur Heart J. 2005; 26(13): 1276-83. PubMed Abstract | Publisher Full Text

17. Burkhoff $\mathrm{D}$, Cohen $\mathrm{H}$, Brunckhorst $\mathrm{C}$, et al.: A randomized multicenter clinical study to evaluate the safety and efficacy of the TandemHeart percutaneous ventricular assist device versus conventional therapy with intraaortic balloon pumping for treatment of cardiogenic shock. Am Heart J. 2006; 152(3): 469.e1-8.

PubMed Abstract | Publisher Full Text

18. Seyfarth M, Sibbing D, Bauer I, et al.: A Randomized Clinical Trial to Evaluate the Safety and Efficacy of a Percutaneous Left Ventricular Assist Device Versus Intra-Aortic Balloon Pumping for Treatment of Cardiogenic Shock Caused by Myocardial Infarction. J Am Coll Cardiol. 2008; 52(19): 1584-8. PubMed Abstract | Publisher Full Text | Faculty Opinions Recommendation

19. Ouweneel DM, Eriksen E, Sjauw KD, et al.: Percutaneous Mechanical Circulatory Support Versus Intra-Aortic Balloon Pump in Cardiogenic Shock After Acute Myocardial Infarction. J Am Coll Cardiol. 2017; 69(3): 278-87. PubMed Abstract | Publisher Full Text

20. Bochaton T, Huot L, Elbaz M, et al:: Mechanical circulatory support with the Impella囚 LP5.0 pump and an intra-aortic balloon pump for cardiogenic shock in acute myocardial infarction: The IMPELLA-STIC randomized study. Arch in acute myocardial infarction: The IMPI
Cardiovasc Dis. 2020; 113(4): 237-43. PubMed Abstract | Publisher Full Text | Faculty Opinions Recommendation

21. Drunner S, Guenther SPW, Lackermair K, et al.: Extracorporeal Life Support in Cardiogenic Shock Complicating Acute Myocardial Infarction. J Am Coll Cardiol. 2019; 73(18): 2355-7.

PubMed Abstract | Publisher Full Text | Faculty Opinions Recommendation

22. Pahuja M, Chehab O, Ranka S, et al.: Incidence and clinical outcomes of stroke in ST-elevation myocardial infarction and cardiogenic shock. Catheter Cardiovasc Interv. 2020.

PubMed Abstract | Publisher Full Text

23. Pahuja M, Ranka S, Chehab O, et al.: Incidence and clinical outcomes of bleeding complications and acute limb ischemia in STEMI and cardiogenic shock. Catheter Cardiovasc Interv. 2020. PubMed Abstract | Publisher Full Text

24. Schrage B, Ibrahim K, Loehn T, et al:: Impella Support for Acute Myocardial Infarction Complicated by Cardiogenic Shock. Circulation. 2019; 139(10): 1249-58.

PubMed Abstract | Publisher Full Text | Faculty Opinions Recommendation

25. A Amin AP, Spertus JA, Curtis JP, et al:: The Evolving Landscape of Impella 
Use in the United States Among Patients Undergoing Percutaneous Coronary Intervention With Mechanical Circulatory Support. Circulation. 2020; 141(4): 273-84.

PubMed Abstract | Publisher Full Text | Faculty Opinions Recommendation

26. Dohruva SS, Ross JS, Mortazavi BJ, et al:: Association of Use of an Intravascular Microaxial Left Ventricular Assist Device vs Intra-aortic Balloon Pump With In-Hospital Mortality and Major Bleeding Among Patients With Acute Myocardial Infarction Complicated by Cardiogenic Shock. JAMA. 2020; 10: e200254.

PubMed Abstract | Publisher Full Text | Free Full Text

Faculty Opinions Recommendation

27. Udesen NJ, Møller JE, Lindholm MG, et al:: Rationale and design of DanGer shock: Danish-German cardiogenic shock trial. Am Heart J. 2019; 214: 60-8. PubMed Abstract | Publisher Full Text

28. Sotomi $\mathrm{Y}$, Sato N, Kajimoto K, et al.: Impact of pulmonary artery catheter on outcome in patients with acute heart failure syndromes with hypotension or receiving inotropes: From the ATTEND Registry. Int J Cardiol. 2014; 172(1): $165-72$.

PubMed Abstract | Publisher Full Text

29. Hernandez GA, Lemor A, Blumer V, et al:: Trends in Utilization and Outcomes of Pulmonary Artery Catheterization in Heart Failure With and Without Cardiogenic Shock. J Card Fail. 2019; 25(5): 364-71. PubMed Abstract | Publisher Full Text | Faculty Opinions Recommendation

30. C Basir MB, Schreiber T, Dixon S, et al:: Feasibility of early mechanical circulatory support in acute myocardial infarction complicated by cardiogenic shock: The Detroit cardiogenic shock initiative. Catheter Cardiovasc Interv. 2018; 91(3): 454-61.

PubMed Abstract | Publisher Full Text | Faculty Opinions Recommendation

31. Vallabhajosyula S, Shankar A, Patlolla SH, et al.: Pulmonary artery catheter use in acute myocardial infarction-cardiogenic shock. ESC Heart Fail. 2020; 7(3): 1234-45

PubMed Abstract | Publisher Full Text | Free Full Text

Faculty Opinions Recommendation

32. Kapur NK, Hirst C, Zisa D: Advances in Vascular Post-Closure With Impella. Cardiovasc Revasc Med. 2019; 20(2): 94-5. PubMed Abstract | Publisher Full Text

33. Alushi B, Douedari A, Froehlig G, et al:: Impella versus IABP in acute myocardial infarction complicated by cardiogenic shock. Open Heart. 2019 6(1): e000987.

PubMed Abstract | Publisher Full Text | Free Full Text |

Faculty Opinions Recommendation

34. Pieri M, Sorrentino T, Oppizzi M, et al:: The role of different mechanical circulatory support devices and their timing of implantation on myocardial damage and mid-term recovery in acute myocardial infarction related cardiogenic shock. J Interv Cardiol. 2018; 31(6): 717-24.

PubMed Abstract | Publisher Full Text | Faculty Opinions Recommendation

35. Ferguson $\mathrm{JJ}$, Cohen M, Freedman RJ, et al:: The current practice of intra-aortic balloon counterpulsation: Results from the Benchmark Registry. J Am Coll Cardiol. 2001; 38(5): 1456-62.

PubMed Abstract | Publisher Full Tex

36. Cohen M, Urban P, Christenson JT, et al: Intra-aortic balloon counterpulsation in US and non-US centres: Results of the Benchmark Registry. Eur Heart $J$. 2003; 24(19): 1763-70.

PubMed Abstract | Publisher Full Text

37. Stone GW, Ohman EM, Miller MF, et al.: Contemporary Utilization and Outcomes of Intra-Aortic Balloon Counterpulsation in Acute Myocardial Infarction:The Benchmark Registry. J Am Coll Cardiol. 2003; 41(11): 1940-5. PubMed Abstract | Publisher Full Text

38. Siriwardena M, Pilbrow A, Frampton C, et al.: Complications of intra-aortic balloon pump use: Does the final position of the IABP tip matter? Anaesth Intensive Care. 2015; 43(1): 66-73. PubMed Abstract | Publisher Full Tex

39. Cohen M, Dawson MS, Kopistansky C, et al:: Sex and other predictors of intraaortic balloon counterpulsation-related complications: Prospective study of 1119 consecutive patients. Am Heart J. 2000; 139(2 Pt 1): 282-7. PubMed Abstract | Publisher Full Text

40. Valente $\mathrm{S}$, Lazzeri $\mathrm{C}$, Chiostri $\mathrm{M}$, et al:: Intra-aortic balloon pump in intensive cardiac care: A registry in Florence. Int J Cardiol. 2011; 146(2): 238-9. PubMed Abstract | Publisher Full Text

41. Davidavicius G, Godino C, Shannon J, et al:: Incidence of Overall Bleeding in Patients Treated With Intra-Aortic Balloon Pump During Percutaneous Coronary Intervention: 12-year Milan Experience. JACC Cardiovasc Interv. 2012; 5(3): 350-7.

PubMed Abstract | Publisher Full Text

42. Ternus BW, Jentzer JC, El Sabbagh A, et al:: Percutaneous Mechanical Circulatory Support for Cardiac Disease: Temporal Trends in Use and Complications Between 2009 and 2015. J Invasive Cardiol. 2017; 29(9): 309-13. PubMed Abstract

43. Schwartz BG, Ludeman DJ, Mayeda GS, et al:: Treating Refractory Cardiogenic Shock With the TandemHeart and Impella Devices: A Single Center Experience. Cardiol Res. 2012; 3(2): 54-66. PubMed Abstract | Publisher Full Text | Free Full Text
44. Mackenzie DJ, Wagner WH, Kulber DA, et al:: Vascular complications of the intra-aortic balloon pump. Am J Surg. 1992; 164(5): 517-21.

PubMed Abstract | Publisher Full Text

45. Ö̈zen Y, Aksut M, Cekmecelioglu D, et al.: Intra-aortic balloon pump experience: A single center study comparing with and without sheath insertion. J Cardiovasc Thorac Res. 2018; 10(3): 144-8. PubMed Abstract | Publisher Full Text | Free Full Text| Faculty Opinions Recommendation

46. Arceo A, Urban P, Dorsaz PA, et al.: In-Hospital Complications of Percutaneous Intraaortic Balloon Counterpulsation. Angiology. 2016; 54(5): 577-85. PubMed Abstract | Publisher Full Text

47. Dick $P$, Mlekusch W, Delle-Karth G, et al:: Decreasing incidence of critical limb ischemia after intra-aortic balloon pump counterpulsation. Angiology. 2009; 60(2): 235-41.

PubMed Abstract | Publisher Full Text

48. Eltchaninoff H, Dimas AP, Whitlow PL: Complications associated with percutaneous placement and use of intraaortic balloon counterpulsation. Am J Cardiol. 1993; 71(4): 328-32.

PubMed Abstract | Publisher Full Text

49. Meisel S, Shochat M, Sheikha SA, et al.: Utilization of low-profile intra-aortic balloon catheters inserted by the sheathless technique in acute cardiac patients: Clinical efficacy with a very low complication rate. Clin Cardiol. 2004 27(11): 600-4

PubMed Abstract | Publisher Full Text | Free Full Text

50. Annamalai SK, Esposito ML, Jorde L, et al:: The Impella Microaxial Flow Catheter Is Safe and Effective for Treatment of Myocarditis Complicated by Cardiogenic Shock: An Analysis From the Global cVAD Registry. J Card Fail. 2018; 24(10): 706-10.

PubMed Abstract | Publisher Full Text

51. O'Neill WW, Schreiber T, Wohns DHW, et al.: The Current Use of Impella 2.5 in Acute Myocardial Infarction Complicated by Cardiogenic Shock: Results from the USpella Registry. J Interv Cardiol. 2014; 27(1): 1-11. PubMed Abstract | Publisher Full Text | Free Full Text | Faculty Opinions Recommendation

52. Jensen PB, Kann SH, Veien KT, et al:: Single-centre experience with the Impella CP, $\mathbf{5 . 0}$ and RP in 109 consecutive patients with profound cardiogenic shock. Eur Heart J Acute Cardiovasc Care. 2018; 7(1): 53-61. PubMed Abstract | Publisher Full Text | Faculty Opinions Recommendation

53. Karatolios K, Chatzis G, Markus B, et al:: Impella support compared to medical treatment for post-cardiac arrest shock after out of hospital cardiac arrest. Resuscitation. 2018; 126: 104-10.

PubMed Abstract | Publisher Full Text | Faculty Opinions Recommendation

54. Karami M, den Uil CA, Ouweneel DM, et al:: Mechanical circulatory support in cardiogenic shock from acute myocardial infarction: Impella CP/5.0 versus ECMO. Eur Heart J Acute Cardiovasc Care. 2020; 9(2): 164-72. PubMed Abstract | Publisher Full Text | Faculty Opinions Recommendation

55. Basir MB, Kapur NK, Patel K, et al:: Improved Outcomes Associated with the use of Shock Protocols: Updates from the National Cardiogenic Shock Initiative. Catheter Cardiovasc Interv. 2019; 93(7): 1173-83. PubMed Abstract | Publisher Full Text

56. Kaki A, Blank N, Alraies MC, et al:: Axillary Artery Access for Mechanical Circulatory Support Devices in Patients With Prohibitive Peripheral Arteria Disease Presenting With Cardiogenic Shock. Am J Cardiol. 2019; 123(10): 1715-21.

PubMed Abstract | Publisher Full Text | Faculty Opinions Recommendation

57. Lauten A, Engström AE, Jung C, et al:: Percutaneous Left-Ventricular Support With the Impella-2.5-assist Device in Acute Cardiogenic Shock: Results of the Impella-EUROSHOCK-registry. Circ Heart Fail. 2013; 6(1): 23-30. PubMed Abstract | Publisher Full Text

58. Ouweneel DM, de Brabander J, Karami M, et al:: Real-life use of left ventricular circulatory support with Impella in cardiogenic shock after acute myocardial infarction: 12 years AMC experience. Eur Heart J Acute Cardiovasc Care. 2019; 8(4): 338-49.

PubMed Abstract | Publisher Full Text | Free Full Text |

Faculty Opinions Recommendation

59. Badiye AP, Hernandez GA, Novoa I, et al:: Incidence of Hemolysis in Patients with Cardiogenic Shock Treated with Impella Percutaneous Left Ventricular Assist Device. ASAIO J. 2016; 62(1): 11-4

PubMed Abstract | Publisher Full Text

60. Esposito ML, Morine KJ, Annamalai SK, et al: Increased Plasma-Free Hemoglobin Levels Identify Hemolysis in Patients With Cardiogenic Shock and a Trans valvular Micro-Axial Flow Pump. Artif Organs. 2019; 43(2): 125-31. PubMed Abstract | Publisher Full Text

61. Lamarche $\mathrm{Y}$, Cheung A, Ignaszewski A, et al:: Comparative outcomes in cardiogenic shock patients managed with Impella microaxial pump or extracorporeal life support. J Thorac Cardiovasc Surg. 2011; 142(1): 60-5. PubMed Abstract | Publisher Full Text

62. Anderson M, Morris DL, Tang D, et al:: Outcomes of patients with right ventricular failure requiring short-term hemodynamic support with the Impella RP device. J Heart Lung Transplant. 2018; 37(12): 1448-58. PubMed Abstract | Publisher Full Text 
63. Chamogeorgakis T, Rafael A, Shafii AE, et al.: Which is better: a miniaturized percutaneous ventricular assist device or extracorporeal membrane oxygenation for patients with cardiogenic shock? ASAIO J. 2013; 59(6): 607-11.

PubMed Abstract | Publisher Full Text

64. Hoefer D, Ruttmann E, Poelzl G, et al:: Outcome evaluation of the bridge-tobridge concept in patients with cardiogenic shock. Ann Thorac Surg. 2006; 82 28-33.

PubMed Abstract | Publisher Full Text

65. Koerner MM, Harper MD, Gordon CK, et al:: Adult cardiac veno-arterial extracorporeal life support (VA-ECMO): Prevention and management of acute complications. Ann Cardiothorac Surg. 2019; 8(1): 66-75. PubMed Abstract | Publisher Full Text | Free Full Text | Faculty Opinions Recommendation

66. Lorusso R, Barili F, Di Mauro M, et al.: In-Hospital Neurologic Complications in Adult Patients Undergoing Venoarterial Extracorporeal Membrane Oxygenation: Results From the Extracorporeal Life Support Organization Registry. Crit Care Med. 2016; 44(10): e964-e972.

PubMed Abstract | Publisher Full Text

67. Kolla S, Lee WA, Hirschl RB, et al.: Extracorporeal Life Support for Cardiovascular Support in Adults. ASAIO J. 1996; 42(5): M809-818. PubMed Abstract | Publisher Full Text

68. Gulkarov I, Bobka T, Elmously A, et al:: The Effect of Acute Limb Ischemia on Mortality in Patients Undergoing Femoral Venoarterial Extracorporeal Membrane Oxygenation. Ann Vasc Surg. 2020; 62: 318-25. PubMed Abstract | Publisher Full Text | Faculty Opinions Recommendation

69. CYau P, Xia Y, Shariff S, et al.: Factors Associated with Ipsilateral Limb Ischemia in Patients Undergoing Femoral Cannulation Extracorporeal Membrane Oxygenation. Ann Vasc Surg. 2019; 54: 60-5.

PubMed Abstract | Publisher Full Text | Faculty Opinions Recommendation

70. Avalli L, Sangalli F, Migliari M, et al:: Early vascular complications after percutaneous cannulation for extracorporeal membrane oxygenation for cardiac assist. Minerva Anestesiol. 2016; 82(1): 36-43. PubMed Abstract

71. Wong JK, Melvin AL, Joshi DJ, et al:: Cannulation-Related Complications on Veno-Arterial Extracorporeal Membrane Oxygenation: Prevalence and Effect on Mortality. Artif Organs. 2017; 41(9): 827-34. PubMed Abstract | Publisher Full Text

72. Ranney DN, Benrashid E, Meza JM, et al.: Vascular Complications and Use of a Distal Perfusion Cannula in Femorally Cannulated Patients on Extracorporeal Membrane Oxygenation. ASAIO J. 2018; 64(3): 328-33. PubMed Abstract | Publisher Full Text | Faculty Opinions Recommendation

73. Foley $\mathrm{PJ}$, Morris RJ, Woo EY, et al.: Limb ischemia during femoral cannulation for cardiopulmonary support. J Vasc Surg. 2010; 52(4): 850-3. PubMed Abstract | Publisher Full Text

74. Lamb KM, DiMuzio PJ, Johnson A, et al:: Arterial protocol including prophylactic distal perfusion catheter decreases limb ischemia complications in patients undergoing extracorporeal membrane oxygenation. J Vasc Surg. 2017; 65(4) 1074-9.

PubMed Abstract | Publisher Full Text

75. Belle L, Mangin L, Bonnet $\mathrm{H}$, et al.: Emergency extracorporeal membrane oxygenation in a hospital without on-site cardiac surgical facilities. Eurolntervention. 2012; 8(3): 375-82. PubMed Abstract | Publisher Full Text

76. Bermudez CA, Rocha RV, Toyoda Y, et al.: Extracorporeal Membrane Oxygenation for Advanced Refractory Shock in Acute and Chronic
Cardiomyopathy. Ann Thorac Surg. 2011; 92(6): 2125-31.

PubMed Abstract | Publisher Full Text

77. Kim H, Lim SH, Hong J, et al:: Efficacy of veno-arterial extracorporeal membrane oxygenation in acute myocardial infarction with cardiogenic shock. Resuscitation. 2012; 83(8): 971-5.

PubMed Abstract | Publisher Full Text

78. Esper SA, Bermudez C, Dueweke EJ, et al: Extracorporeal membrane oxygenation support in acute coronary syndromes complicated by cardiogenic shock. Catheter Cardiovasc Interv. 2015; 86(Suppl 1): S45-S50. PubMed Abstract | Publisher Full Text

79. Loforte A, Montalto A, Ranocchi F, et al:: Peripheral extracorporeal membrane oxygenation system as salvage treatment of patients with refractory cardiogenic shock: Preliminary outcome evaluation. Artif Organs. 2012; 36(3): E53-61.

PubMed Abstract | Publisher Full Text

80. Moraca RJ, Wanamaker KM, Bailey SH, et al:: Salvage Peripheral Extracorporeal Membrane Oxygenation Using Cobe Revolution $₫$ Centrifugal Pump as a Bridge to Decision for Acute Refractory Cardiogenic Shock. J Card Surg. 2012; 27(4): 521-7.

PubMed Abstract | Publisher Full Text

81. Pagani FD, Aaronson KD, Swaniker F, et al:: The use of extracorporeal life suppor in adult patients with primary cardiac failure as a bridge to implantable left ventricular assist device. Ann Thorac Surg. 2001; 71(3 Suppl): S77-S81. PubMed Abstract | Publisher Full Text

82. Wu MY, Lee MY, Lin CC, et al:: Resuscitation of non-postcardiotomy cardiogenic shock or cardiac arrest with extracorporeal life support: The role of bridging to intervention. Resuscitation. 2012; 83(8): 976-81. PubMed Abstract | Publisher Full Text

83. Formica F, Avalli L, Colagrande L, et al.: Extracorporeal membrane oxygenation to support adult patients with cardiac failure: Predictive factors of 30-day mortality. Interact Cardiovasc Thorac Surg. 2010; 10(5): 721-6. PubMed Abstract | Publisher Full Text

84. Batra J, Toyoda N, Goldstone AB, et al.: Extracorporeal Membrane Oxygenation in New York State: Trends, Outcomes, and Implications for Patient Selection. Circ Heart Fail. 2016; 9(12): e003179. PubMed Abstract | Publisher Full Text

85. Vallabhajosyula S, Bell MR, Sandhu GS, et al:: Complications in Patients with Acute Myocardial Infarction Supported with Extracorporeal Membrane Oxygenation. J Clin Med. 2020; 9(3): 839 PubMed Abstract | Publisher Full Text | Free Full Text | Faculty Opinions Recommendation

86. Scheidt S, Wilner G, Mueller H, et al.: Intra-aortic balloon counterpulsation in cardiogenic shock. Report of a co-operative clinical trial. N Engl J Med. 1973; 288(19): 979-84.

PubMed Abstract | Publisher Full Text

87. Lee L, Bates ER, Pitt B, et al.: Percutaneous transluminal coronary angioplasty improves survival in acute myocardial infarction complicated by cardiogenic shock. Circulation. 1988; 78(6): 1345-51. PubMed Abstract | Publisher Full Tex

88. Hochman JS, Sleeper LA, Webb JG, et al:: Early Revascularization in Acute Myocardial Infarction Complicated by Cardiogenic Shock. SHOCK Investigators. Should We Emergently Revascularize Occluded Coronaries for Cardiogenic Shock. N Engl J Med. 1999; 341(9): 625-34. PubMed Abstract | Publisher Full Text | Faculty Opinions Recommendation

89. Kapur NK, Alkhouli MA, DeMartini TJ, et al.: Unloading the Left Ventricle Before Reperfusion in Patients With Anterior ST-Segment-Elevation Myocardial Infarction. Circulation.. 2019; 139(3): 337-346.

PubMed Abstract | Publisher Full Text 


\section{Open Peer Review}

\section{Current Peer Review Status:}

\section{Editorial Note on the Review Process}

Faculty Reviews are review articles written by the prestigious Members of Faculty Opinions. The articles are commissioned and peer reviewed before publication to ensure that the final, published version is comprehensive and accessible. The reviewers who approved the final version are listed with their names and affiliations.

\section{The reviewers who approved this article are:}

\section{Version 1}

\section{Saraschandra Vallabhajosyula}

Department of Cardiovascular Medicine, Mayo Clinic, Rochester, MN, USA

Competing Interests: No competing interests were disclosed.

\section{Daniel A. Jones}

Department of Cardiology, Barts Heart Centre, London, UK

Competing Interests: No competing interests were disclosed.

The benefits of publishing with F1000Research:

- Your article is published within days, with no editorial bias

- You can publish traditional articles, null/negative results, case reports, data notes and more

- The peer review process is transparent and collaborative

- Your article is indexed in PubMed after passing peer review

- Dedicated customer support at every stage

For pre-submission enquiries, contact research@f1000.com 